\title{
CONSUMERS' RESPONSES TO ADS ON SOCIAL NETWORKING SITES: A SYSTEMATIC LITERATURE REVIEW (SLR)
}

\author{
Hossam Deraz \\ Dr., School of Business, Engineering and Science - Halmstad University, Sweden
}

\begin{abstract}
A consequence of the growing number of the studies concerning ads on social networking sites, and the failure to provide an in-depth analysis of that stream of research is the need to adopt systematic approaches to assess and aggregate research outcomes. This article presents an up-to-date review of peer-reviewed relevant articles to consumers' responses to advertisements on SNSs. It helps to identify 100 relevant studies published in the period 2009-2017 from different management and social science fields; including marketing, advertising, communication, social science, and relationship management. It reflects six predominate research trends; 1) Antecedents of acceptance or avoidance of ads 2) Consumers' perception and assessment of ads' value 3) consumers' attitude towards ads 4) Consumers' purchase intention 5) Consumers' referral mechanism, and 6) Benefits gained. Also, the topics researched and major results, year of publication, journal, theoretical framework, research method, sampling, and means of analysis were examined for each article. It helps to provide an objective summary of research evidence on the antecedents of consumers' responses to ads on social networking sites. It concludes by offering an agenda for future studies.
\end{abstract}

\section{KEYWORDS}

Marketing, Communication, Advertising, Social Networking Site, Consumer Response, Consumer Attitude

\section{INTRODUCTION}

The central focus of this study is social networking sites (SNSs), which are mainly used to maintain private relationships and contacts such as Facebook, Instagram, and Twitter (Schrammel, Köffel \& Tscheligi, 2009). In recent years, the increasingly widespread use of SNSs has gradually resulted in a shift in the advertising platforms from traditional media to those sites. Marketers aim to gain additional advantages from using SNSs such as spreading positive WOM (Zhang \& Mao, 2016), building brand image and brand equity (Dehaghani \& Tumer, 2015; Hanaysha, 2016), or enhancing purchase intention (Duffet, 2015a; Knoll \& Schramm, 2015; Zhang \& Mao, 2016). Besides, SNSs help companies to gain fresh, profound insights into what customers need and want (Kotler et al., 2016). In regard, scholars more frequently investigate a widening range of phenomena to explain ads on the social networking site (SNSAs) as a marketing tool.

Investigations about consumers' responses to ads captured the interest of ad researchers' long time ago (Olney, Holbrook \& Batra, 1991). From the SNSs context, researchers used a wide range of research phenomena to explore different levels of consumers' responses to SNSAs. They had different disciplines, they used a wide range of theory, and they were inevitably limited in scope regarding their flows and sampling variation. That results in some conflicting findings. In such a situation, it is not always clear what the overall picture is, or which results are more reliable and should be used as the basis for theory and management decision. Yet, there is no evidence of existing studies providing an in-depth analysis of this research context. Almost all the existing literature reviews concerned online advertising (e.g., Cho \& Khang, 2006; Kim \& McMillan, 2008), or investigated bodies of research related to ads on social media in general, such as Knoll's (2016) study, which reviewed ads on social media up to 2014. In this regard, the primary purpose of this article is to provide an in-depth analysis of investigations into the consumers' responses to SNSAs. Also, it aimed to identify the major trends and areas of deficit in investigating this research field. Accordingly, the research question proposed is as follow:

1. What are the major research trends and areas of deficit in articles concerning the consumers' responses to SNSAs? 


\section{SELECTION OF ARTICLES}

A search was conducted through two multiple bibliographic databases (OneSearch \& Scopus). In addition to reviewing some of the top marketing journals. The OneSearch database was selected as it is a Halmstad University mega index database containing the majority of resources from Emerald, IEEE Xplore, Inderscience publishers, JSTOR, Libris, Sage journals online, ScienceDirect, Taylor \& Francis online, SpringerLink, Web of Science, Wiley online library, and others. To ensure the relevance of the collected studies to SNSAs, they were required to contain the term 'advertise' (e.g., advertising, advertiser, ads, ad, advertisement, or marketing promotion) in their titles in one of three search fields. In the second search field, the articles were required to contain one of the following terms in their titles: 'social networking sites,' 'social network site,' 'social media,' 'online social network', 'Facebook, or 'Twitter.' Finally, the term 'Facebook' was searched throughout the text of the articles because it is currently among the most popular SNSs: The name of this site is in almost all the articles on SNSs and is sometimes used in the title, abstract, or keywords. This criterion ensured that the articles selected also contained a reference to SNSs. The search was limited to full text, peer-reviewed academic papers in management domain and social science subjects, such as 'advertising', 'marketing', 'public relation', 'communication management', 'social science', 'purchase intention', 'brand awareness,' and so on. Peer-reviewed journals were considered based on their knowledge validity and their highest impact on the research field (Podsakoff et al., 2005). The search revealed 398 articles, which were further limited to those directly related to testing a sort of consumers' responses. Also, articles examined other media-type not SNSs were excluded (e.g., Miller \& Lammas 2012; Smith, Fischer \& Yongjian, 2012). After applying this criterion, the final dataset comprised a shortlist of 100 articles from 29 countries that were published between 2009 and 2017.

\section{RESULTS}

\subsection{Journals and years of publication}

All the 100 articles identified were published from 2009 to 2017 (see Figure 1). The most significant number of publications was recorded for the year 2017 (25 articles, $25 \%$ ). Moreover, the majority of these articles (75\%) were published during the last four years (2014-2017). These facts notably highlight the trend of an increasing number of journal publications concerning the consumers' responses to SNSAs. This growing trend in the publications indicates the importance of this area and increasing awareness among researchers investigating SNSs. SNSs is still a relatively new phenomenon that is continually changing (Khang, Ki \& Ye, 2012). These facts serve to highlight the value of up-to-date review, as recommended by Knoll (2016).

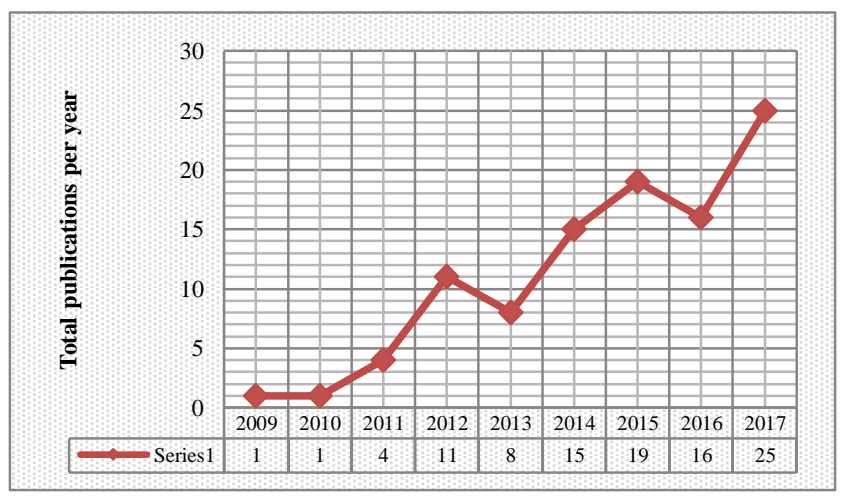

Figure 1. Number of articles published per year

Looking at the journal outlets (see table 1), the 100 articles were published in 68 journals. $85.3 \%$ of the total were journals specialized in different business and marketing disciplines such as general marketing (18 Journals), management and business (22 Journals), advertising (5 Journals), consumer behavior (4 Journals), Electronic Commerce (4 Journals), and communication (5 Journals). The remaining 51 articles were published in different 51 journals. This diversity indicates that there is not a high concentration of research in this field within a specific journal. 


\subsection{Country of Affiliation}

The 100 articles identified were affiliated with institutions in 33 different countries, as shown in Figure 2. According to the findings, researchers from US institutions published the highest amount of publications per country of affiliation (22 articles, $22 \%$ of the total publications).

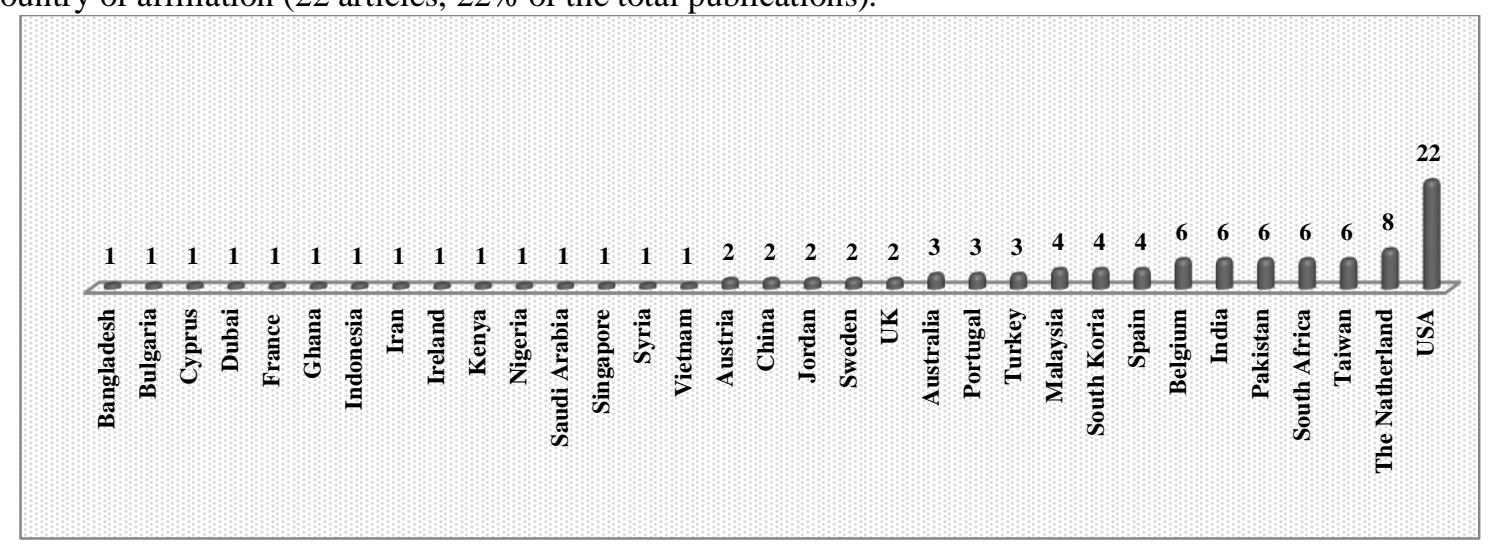

Figure 2. Total publications per countries of author(s) affiliation

Moreover, researchers from the European institutions had 34 articles (34\% of the total). Netherlands (8 articles), Belgium (5 articles), Spain (4 articles), Turkey and Portugal (3 articles each), Austria, Sweden and UK ( 2 articles each), and Bulgaria, Cyprus, Ireland and France (1 article each).

That was followed by researchers from the Asian institutions published 33 articles (33\% of the total). India, Pakistan, and Taiwan (6 articles each), Malaysia and South Koria (4 articles each), then China (2 articles) and Bangladesh, Iran, Indonesia, Singapore, and Vietnam (1 article each).

Researchers from Africans and Middle East institutions followed the European institutions by publishing 12 articles (12\% of the total). African and the Middle East institutions led by South African (4 articles), Chana (2 articles), then Dubai, Jordan, Kenya, Nigeria, Saudi Arabia and Syria (one article each). Finally, researchers from the Australian institutions published three article in 2012, 2014 and 2017.

\subsection{Research Topics}

Based on the primary subjects the author(s) aimed to examine in their articles, and the steps of consumers' responses to ads as presented in the association model of the advertising communication process (Preston, 1982) the body of research concerning the consumers' responses to SNSAs is classified into six main research trends as follow;

\subsubsection{Acceptance and Avoidance of Ads}

Seventeen articles (17\% of the total) investigated factors encouraging or inhabiting ads-clicking on SNSs. Zeng, Huang and Dou (2009) were the first to write about this research trend, followed by (Kelly, Kerr \& Drennan, 2010; Hadija, Barnes \& Hair, 2012; Li, Lee \& Lien, 2012; Barreto, 2013; Gironda \& Korgaonkar, 2014; Li, Lin \& Chiu, 2014; Mahalangu, 2014; Mir, 2014; Aguirre et al., 2015; De Keyzer, Dens and De Pelsmacker, 2015; Mir, 2015; Pinho \& Soares, 2015; Kim, Kang, Choi \& Sung, 2016; Van den Broeck, Poels \& Walrave, 2017; Lee et al., 2017; Mir, 2017).

\subsubsection{Perception \& Assessment of Ads' Value}

Fourteen articles (14\% of the total) had a focus on testing factors' predicting consumers' beliefs toward SNSAs. According to the different aims of the articles under this research trend, authors were either concerned about the assessments of ads' value or to explore users' perception toward specific constructs such as trust, value corruption, consumer boundaries, image belief, or media types. The assessment of ads' value was addressed by nine articles (Logan, Bright \& Gangadharbtla, 2012, Saxena \& Khanna, 2013; Dao et al., 2014; Dar et al., 2014; Deraz, Awuah \& Abraha, 2015a; Deraz, Awuah \& Abraha, 2015b; Haida \& Rahim 2015; Martínez-Navarro \& Bigné 2017; Shareef et al. 2017). While the other four studies explored different constructs such as trust (Abdelkaader, 2013), beliefs (Natarajan et al., 2014; Beuckels, Cauberghe \& Hudders, 2017), feelings (Morris, Choi \& Ju, 2016), and advertising literacy (Lawlor, Dunne \& Rowley, 2016). 


\subsubsection{The Consumers' Attitude towards SNSAs}

The third research trend involved antecedents influencing consumers' attitude toward SNSAs. It focuses on individuals' cognitive response which represents the verbal statements of belief (Jain, 2014). This trend of research is the most dominant. Twenty four articles (24\% of the total) investigated the cognitive antecedents of SNSAs as perceived by SNSs' users (see Chi, 2011; Chu, 2011; Taylor, Lewin \& Strutton, 2011; Kamal \& Chu, 2012; Mir, 2012 Beauchamp, 2013; Yaakop, Marhana, and Khatijah, 2013; Gaber \& Wright, 2014; Sabri \& Michel, 2014; Celebi, 2015; Luna-Nevarez \& Torres, 2015; Boerman \& Kruikemeier, 2016; Can \& Kaya, 2016; Jung et al., 2016; Kim, Jeong \& Hwang, 2016; Shen et al., 2016; Singh, 2016; Walrave et al., 2016; Cole, DeNardin \& Clow, 2017; Dondolo, 2017; Ferreira \& Barbosa, 2017; Mukherjee \& Banerjee, 2017; Tran, 2017; Wang \& Haung, 2017).

\subsubsection{Consumers' Intention to Purchase}

The fourth research trend involved antecedents influencing consumers' intention to purchase advertised products on SNSs. This trend of research is the second dominant one. It had twenty two articles (22\% of the total) (see Bhakuni \& Aronki, 2012; Chang, Chen \& Tan, 2012; Miller \& Lammas, 2012; Yousif, 2012; Chu, Kamal \& Kim, 2013; Okazaki \& Taylor, 2013; Tan, Kwek \& Li, 2013; Campbell, Ferraro \& Sands, 2014; van Noort, Antheunis \& Verlegh, 2014; Voorveld \& van Noort, 2014; Boateng \& Okoe, 2015; Dehghani \& Tumer, 2015; Duffett, 2015a; Eleboda \& Majekodunmi, 2015; Zhang \& Peng, 2015; Lee \& Hong, 2016; Zhang \& Mao, 2016; Hajarian et al., 2017; John et al., 2017; Kim, Seely \& Jung, 2017; Rambe \& Jafeta, 2017; Thornhill, Xie \& Lee, 2017; Vanwesenbeeck, Ponnet \& Walrave, 2017; Vassileva, 2017; Zarouali et al., 2017).

\subsubsection{Consumers' Referral Intention}

The SNSs users' referral intention to share, forward, recommend, or comment on SNSAs is the fifth trend of research that was investigated by some researchers. Sixten articles (16\% of the total) mainly focused on factors predicting the consumers' referral mechanism on SNSs and their intention to engage in WOM (see Royo-Vela \& Casamassima, 2011; De Vries, Gensler \& Leeflang, 2012; Clark \& Çalli, 2014; Liu, 2014; Okazaki, Rubio \& Campo, 2014; Kim, Lee \& Yoon, 2015; Knoll \& Schramm, 2015; Lin, Li \& Wu, 2015; Hayes, King \& Ramirez Jr., 2016; Ketelaar et al., 2016; Arli \& Dietrich, 2017; Boerman, Willemsen \& Van Der Aa, 2017; Tinko, 2017).

\subsubsection{Gained Benefits}

The last identified research trend is the gained benefits of using SNSs as advertising platforms. Just five studies had the main focus on this research trend. They investigated the role of SNSAs in creating brand awareness and brand equity (Alhaddad, 2015; Duffet, 2015b; Hanaysha, 2016), the role of building corporate image on Facebook users' behavioural response to SNSAs (Amegbe, Owino \& Kerubo, 2017), and the role of Facebook ads to gain customer relationship management and to promote new products (Ertunga, 2017).

\subsection{Theoretical Framework}

One of the aims of reviewing the literature is to establish the type of theory(s) used to examine the questions in a related study. According to the coding process, 65 articles (65\% of total) used an explicit theoretical framework, presented testable hypotheses or generalizations based on theory, or derived theory from systematic observations. Researchers investigated 25 different theories; the most used theories were as follows:

1. The social influence theory (11 articles) (see Zeng, Huang, \& Dou, 2009; Chi, 2011; Chang, Chen \& Tan, 2012; Li, Lee \& Lien, 2012; Li, Lin \& Chiu, 2014; van Noort, Antheunis \& Verlegh, 2014; Knoll \& Schramm, 2015; Lin, Li \& Wu, 2015; Pinho \& Soares, 2015; Hayes, King \& Ranirez Jr., 2016; Lee \& Hong, 2016; Singh, 2016).

2. Ducoffe's $(1995,1996)$ model of ads' value (9 articles) (see Logan, Bright \& Gangadhar-batla, 2012; Saxena \& Khanna, 2013; Dar et al., 2014; Deraz, Awuah \& Abraha 2015a; Deraz, Awuah \& Abraha 2015b; Haida \& Rahim, 2015; Natarjan et al., 2015; Jung et al., 2016; Shareef et al., 2017).

3. Pollay and Mittal's (1993) advertising beliefs and attitudes model (5 articles) (see Kamal \& Chu, 2012; Natarajan et al., 2014; Mir, 2015; Natarajan et al., 2015; Dondolo, 2017).

4. Uses \& gratification theory (5 articles) (Taylor, Lewin \& Strutton, 2011; Mir, 2014; Celebi, 2015; Singh, 2016; Mir, 2017)

5. Friested \& Wight's (1984) model of persuasion knowledge (4 articles) (see Boerman \& Kruikemeier, 2016; Lee \& Hong, 2016; Lawlor, Dunne \& Rowley, 2016; Boerman, Willemsen \& van Der Aa 2017). 
6. Consumer behavior theories (3 articles) (see Chu, Kamal \& Kim, 2013; Gironda \& Korgaonkar, 2014; Boateng \& Okoe, 2015).

7. The diffusion of innovation theory (3 articles) (see Eleboda \& Majekodunmi, 2015; Lin, Li \& Wu, 2015; Zhang \& Peng, 2015)

8. Theory of reasoned action (3 articles) (see Kim, Lee \& Yoon, 2015; Lee \& Hong, 2016; Zhang \& Mao, 2016)

9. Brackett and Carr's (2001) model of consumers' attitudes towards advertising (2 articles) - (see Gaber \& Wright, 2014; Deraz, Awuah \& Abraha, 2015a).

10. Theory of brand equity (2 articles) (see Alhaddad, 2015; Hanaysha, 2016).

11. Media richness theory (2 articles) (see Liu, 2014; Rambe \& Jafeta, 2017).

\section{GENERAL CONCLUSIONS AND RESEARCH AGENDA}

This study is the most up-to-date (to December 2017) systematic literature review regarding SNSAs. This study aims to review all possible academic, and peer-reviewed articles address the consumers' responses to SNSAs. This review extends knowledge from existing reviews on online advertising (Cho \& Khang, 2006) and advertising in social media (Khang, Ki \& Ye, 2012; Knoll, 2016) by focusing explicitly on SNSAs. Other types of social media, such as YouTube, and research on private online communities were excluded from this review. In this respect, this review ends by providing a conclusion on each part of the analysis, and finally sets a research agenda for neglected research topics and theoretical and methodological issues.

\subsection{Journals and Years of Publication}

As only two of the 100 articles investigated were published before 2011 (see Figure 1), research related to consumers' responses to SNSAs can be considered a relatively new field. As in the field of social media, the area of researching ads has only recently been developed (Knoll, 2016), and is still a relatively new phenomenon that is continually changing (Khang, Ki \& Ye, 2012). These facts serve to highlight the value of up-to-date review, as recommended by Knoll (2016). Moreover, Figure 1 notably highlights the trend of an increasing number of journal publications concerning consumers' responses to SNSAs. This growing trend in the publications especially the last year (2017 has $25 \%$ of the total) indicates the importance of this area and awareness among scholars to investigate.

By looking at the journal outlets (Table 1 in the appendix), we can see that the 100 articles have been published in 68 journals. $85.3 \%$ of those journals were journals specialized in different business and marketing disciplines such as general marketing (18 Journals), management and business (22 Journals), advertising (5 Journals), consumer behavior (4 Journals), Electronic Commerce (4 Journals), and communication (5 Journals). There were also 10 journals $(14.7 \%)$ in other disciplines such as the economy, fashion, electronic engineering, social science, engineering management, banking, internet research, psychology, information system and so forth. This diversity indicates that there is not a high concentration of research in this field within a specific journal. In general, the small number of articles in this research area and the variety of journals suggest that extensive research is still required to develop knowledge concerning consumers' relation to SNSAs as one of the new marketing tools.

\subsection{Country of Affiliation}

By looking at figure 2, it is clear that researchers were mainly limited to specific affiliations from few countries. That affects the frame of a sample of those studies to be limited to the countries of these affiliations. By considering the effect of culture on SNSs users' behaviour toward SNSAs (see Deraz, Awuah \& Abraha, 2015b; Kamal \& Chu, 2012; Kim, Jeong \& Hwang, 2016) future research could contribute by replicating such studies with more national culture for supporting or negating the existing knowledge, or even by conducting more multi-nationals studies. Also, by replicating the recent findings in cross-cultural studies, we will be able to compare results and to attribute potential differences to culture.

\subsection{Research Populations \& Non-Student Samples}

Regarding sampling methods, all the 96 empirical studies identified used non-probability sampling methods; mainly they used conventional methods to target SNS users. Using convenience methods is logical because of 
the difficulties encountered in generating a random sample from online communities (Sheehan, 2002). However, around $58.3 \%$ of those empirical studies employed convenient samples in the form of college students and adolescents, who are certainly not representative of all SNS users. As a result, their findings are limited to a certain population that only represents around 25\% of the active users of SNSs (Statista, 2015). This limitation may lead to misguiding results concerning SNSAs.

Furthermore, most of the studies identified targeted a specific sampling frame. As a result, the findings often seem applicable only to a particular kind of social media, a specific sample, and a specific situation. Thus, future research concerning SNSAs could widen the frame of reference by drawing on larger samples (nationally and internationally), and by addressing users of different ages and demographic profiles.

\subsection{Main Contributions of the Collected Data}

The following discussion presents the main contributions that may affect the body of research regarding SNSAs.

\subsubsection{The Effect of Ad-Types}

Clark and Çalli's (2014) study is the first article in this review that highlighted the impact of ad-types on Facebook users referral behavior. However, since 2016, scholars gave more intention to compare the impact of different ad-types on the consumers' responses to SNSAs (see. Boerman \& Krunikemier, 2016; Kim, Jeong \& Hwang, 2016; Jung et al., 2016; De Keyzer, Dens \& Warlave, 2017; Ferreira \& Barbosa, 2017; Tran, 2017; Zraouali et al., 2017; Kim, Seely \& Jung; Tinko, 2017).

In sum, all those studies confirmed that SNSs' users have divergent responses to SNSAs' based on different ad-types. With extend, it is not logic to investigate SNSAs in a general question, but we need to be more specific to an identified ad-type while investigating SNSAs. If we do not target specific ad-type, respondents will answer based on their understanding of the ad-type interpreted in their minds. For example, one of them may answer as it is a sponsored story, another as it is re-targeted ad, and the third as it is check-in-ad. That misunderstanding may lead the respondents to give different answers to the same question, which will affect the gained knowledge. Also, we need to identify primary constructs that have effects on each ad-type specifically. That will help future researchers to gain deeper insight, as it will help marketing planners to organize more effective campaigns.

\subsubsection{Defining the Main Constructs}

By looking at the collected studies, we can easily observe that researchers used serval definitions to define a specific construct. They used different items to measure the same construct, which may affect the gained knowledge. For example; Chang, Chen, and Tan (2012), and Lee and Hong (2016) used the construct of purchase intention to explain ads' effectiveness. On the other hand, Li, Lee, and Lien (2012) and Li, Lin and Chiu (2014) used the construct of click-through-rate to explain ads effectiveness. Moreover, Vooroveld and van Noort (2014), and Wang and Huang (2017) used cognitive response attitude as a construct to explain ads' effectiveness. Finally, Ertugan (2017) tested ads effectiveness by its ability to spread information. All these ways are applicable, but they may give different results, and shows that scholars did not follow the same coherence. For that, the research committee of SNSAs needs to give precise definitions to the main constructs related to SNSAs. That way may reduce the contradictory findings and may help future researchers to have clear related definitions.

\subsubsection{Distinguish between Different Types of Social Media}

Up-to-date, researchers keep mixing between social media and social networking sites. According to Schrammel, Köffel, and Tscheligi $(2009 ; 277)$, social media is classified into four main types:

- Business Networking Sites: Which are mainly used to maintain and administer existing and new business contacts such as LinkedIn and private business networks.

- Social Networks: Which are used to maintain private relationships and contacts such as Facebook and Twitter.

- Content and Media Sharing Networks: With a significant focus on sharing content with others and not on maintaining relationships such as Flickr and YouTube.

- Social News and Bookmarking Sites: Such as delicious.com and dig.com, which are used to share and discover entertaining links to news and contents on the web. 
So, all the four types are under the umbrella of SM, but researchers found that different types of SM influence consumers' response to ads each media carries (Prendergast et al., 2009; Dao et al., 2014). Each type possesses own distinct image, personality, and characteristics (Clemons, 2009). Thus, it is not logical to generalize the findings of SM while investigating one of the above types. We need to investigate each type independently, not to research SNSs and bring findings from research about YouTube. Off-course that way of mixing the findings may lead to contradictory findings. To avoid that, future researchers need to be more focus on what they are investigating, not mixing the findings from all the types together. Also, researchers and marketing planners have to focus on each type to find media that receive a more favorable response from the online users, and to gain deeper insights about crucial predictors of each of those media in specific.

\subsubsection{Unconfirmed Constructs}

To create knowledge about the online users' response to SNSAs we have a lot to do. Researchers keep exploring new constructs, but we have a lot of these constructs just have been tested once, and others show adverse effects. We need to keep our eyes on these constructs to confirm their effects on SNSs users' response, and to gain more insights about the refused once. For example, celebrity endorsement as social context ads has a positive influence on the online users' impression towards SNSAs (Hadija, Barnes \& Hair, 2012; Li, Lee \& Lien, 2012; Li, Lin \& Chiu, 2014). However, when it moderated the effect of sponsored Facebook ads on the users' persuasion knowledge, it causes SNS's users to develop distrusting beliefs about that post, which in turn decreases their intention to engage in eWOM (Boerman, Willemsen and Van Der Aa, 2017). As a research community, we need to understand better the reasons behind those different effects of celebrity endorsement. Is it increase the credibility of ads or develop the distracting beliefs?

\subsection{Limitations}

There are two primary constraints and research issues that can be addressed in further studies. First, this study aimed to review all related studies concerning consumers' response to SNSAs and searched a broad range of keywords within two central databases. However, it is difficult to be confident that the 100 articles identified to represent the full range of relevant scholarly publications. Second, this study focused on SNSAs within the broad management domain and did not consider previous studies of communication systems from information technology backgrounds and other studies that not focus on the SNSs' response. Thus, future reviews might explicitly focus on the use of SNSAs without any such limitations

\section{REFERENCES}

Aguirre, E., Mahr, D., Grewal, D., de Ruyter, K. and Wetzels, M. (2015). 'Unraveling the Personalization Paradox: The Effect of Information Collection and Trust-Building Strategies on Online Advertisement Effectiveness', Journal of Retailing, Vol. 91, No. 1, pp. 34-49.

Alhaddad, A. W. (2015). 'The Effect of Advertising Awareness on Brand Equity in Social Media', International Journal of e-Education, e-Business, e-Management and e-Learning, Vol. 5, No. 2, pp. 73-84.

Amegbe, H., Owino, J. O. and Kerubo, O. L. (2017). 'Behavioural Responses to Corporate Image Building Through Social Media Advertising: A Study Among Nairobi Students', Journal of Creative Communications, Vol. 12, No. 3, pp. 223-238

Arli, D. and Dietrich, T. (2017). 'Can Social Media Campaigns Backfire? Exploring Consumers' Attitudes and Word-of-Mouth Toward Four Social Media Campaigns and Its Implications on Consumer-Campaign Identification', Journal of Promotion Management, Vol. 23, No. 6, pp. 834-850.

Baker, M. (2003), 'The marketing book. 5th ed.', Oxford: Elsevier Ltd., p.227.

Barreto, A. M. (2013). 'Do users look at banner ads on Facebook?', Journal of Research in Interactive Marketing, Vol. 7, No. 2, pp. 119-139.

Beauchamp, M. B. (2013). 'Don't Invade My Personal Space: Facebook's Advertising Dilemma', The Journal of Applied Business Research, Vol. 29, No. 1, pp. 91-96.

Beuckels, E., Cauberghe, V. and Hudders, L. (2017). 'How media multitasking reduces advertising irritation: The moderating role of the Facebook wall', Computers in Human Behavior, Vol. 73, pp. 413-419.

Bhakuni, P. and Aronkar, P. (2012). 'Effect of social media advertising on purchase intentions of students - An empirical study conducted in Gwalior city', International Journal of Applied Services Marketing Perspectives, Vol. 1, No. 1.

Boateng, H. and Okoe, A. (2015). 'Consumers' attitude towards social media advertising and their behavioral response - The moderating role of corporate reputation', Journal of Research in Interactive Marketing, Vol. 9, No. 4, pp. 299-312. 
Boerman, S. C., and Kruikemeier, S. (2016). 'Consumer responses to promoted tweets sent by brands and political parties', Computers in Human Behavior, Vol. 65, pp. 285-294.

Boerman, S. C., Willemsen, L. M. and Van Der Aa, E. P. (2017). 'This Post Is Sponsored” Effects of Sponsorship Disclosure on Persuasion Knowledge and Electronic Word of Mouth in the Context of Facebook', Journal of Interactive Marketing, Vol. 38, pp. 82-92.

Brackett, L. K., and Carr, B. N. (2001). 'Cyberspace advertising vs other media: Consumer vs mature student attitudes', Journal of Advertising Research, Vol. 41, No. 5, pp. 23-32.

Campbell, C., Ferraro, C., and Sands, S. (2014) "Segmenting consumer reactions to social network marketing", European Journal of Marketing, Vol. 48 Issue: 3/4, pp.432-452.

Can, L. and Kaya, N. (2016). 'Social networking sites addiction and the effect of attitude towards social network advertising', Procedia - Social and Behavioral Sciences, Vol. 235, pp. 484-492.

Celebi, S. I. (2015). 'How do motives affect attitudes and behaviors toward internet advertising and Facebook advertising?' Computers in Human Behavior, Vol. 51, pp. 312-324.

Chan, C. (2012). 'Marketing the academic library with online social network advertising', Library Management, Vol. 33 No. $8 / 9$, pp. 479-489.

Chang, K. T., Chen, W. and Tan, B. C. (2012). 'Advertising Effectiveness in Social Networking Sites: Social Ties, Expertise, and Product Type', IEEE Transactions on Engineering Management, Vol. 59, No. 4, pp. 634-643.

Chi, H. (2011). 'Interactive digital advertising Vs. virtual brand community: Exploratory study of user motivation and social media marketing responses in Taiwan', Journal of Interactive Advertising, Vol. 12, No. 1, pp. 44-61.

Cho, C. and Khang, H. (2006). 'The State of Internet-Related Research in Communications, Marketing, and Advertising: 1994-2003', Journal of Advertising, Vol. 35, No. 3, pp. 143-163.

Chu, S., Kamal, S. and Kim, Y. (2013), 'Understanding consumers' responses toward social media advertising and purchase intention toward luxury products', Journal of Global Fashion Marketing, Vol. 4, No. 3, pp. 158-174.

Clark, L. and Çalli, L (2014). 'Personality types and Facebook advertising: An exploratory study'. Journal of Direct, Data and Digital Marketing Practice, Vol. 15, No. 4, pp. 327-336.

Clemons, E. K. (2009). 'The complex problem of monetizing virtual electronic social networks'. Decision Support Systems, Vol. 48, No. 1, 46-56.

Cole, H. S., DeNardin, H. S. and Clow, K. E. (2017). 'Small Service Businesses: Advertising Attitudes and The Use of Digital and Social Media Marketing', Services Marketing Quarterly, Vol. 38, No. 4, pp. 203-212.

Cooper, D. R., and Schindler, P. S. (2006). 'Business Research Methods, 9 Ed.', McGraw-Hill Irwin.

Dao, W., Le, A., Cheng, J., and Chen, D. (2014). 'Social media advertising value; the case of transitional economies in Southeast Asia', International Journal of Advertising, Vol. 33, No. 2, pp. 271-294.

Dar, N., Ahmed, M., Muzaffar, M., Nawaz, K. and Zahid Z. (2014). 'Facebook versus Television: Advertising Value Perception Among Students'. International Journal of Business and Management Invention, Vol 3, No. 9, pp. 61-70.

Dehaghani, M. and Tumer, M. (2015). 'A research on the effectiveness of Facebook advertising in enhancing purchase intention of consumers', Computers in Human Behavior, No. 49, pp. 597-600.

de Keyzer, Dens and de Pelsmacker (2015). 'Is this for me? How Consumers Respond to Personalized Advertising on Social Network Sites', Journal of Interactive Advertising, Vol. 15, No. 2, pp. 124-134.

de Vries, L., Gensler, S., and Leefflang, P. S. H. (2012). 'Popularity of Brand Posts on Brand Fan Pages: An Investigation of the Effects of Social Media Marketing', Journal of Interactive Marketing, No. 26, pp. 83-91.

den Broeck, E. V., Poels, K. and Walrave, M. (2017). 'A Factorial Survey Study on the Influence of Advertising Place and the Use of Personal Data on User Acceptance of Facebook Ads', American Behavioral Scientist, Vol. 61, No. 7, pp. 651-671.

Deraz, H., Awuah, G. and Abraha, D. (2015a). 'Factors Predicting Consumers' Assessment of Ads on Social Networking Sites', International Journal of Digital Information and Wireless Communications (IJDIWC), Vol. 5, No. 2, pp. 111-123.

Deraz, H., Awuah, G. and Abraha, D. (2015b). 'The Effect of Culture on the Consumers' Assessment of Ads on Social Networking Sites; Cross-cultural analysis', IEEE Xplore digital library, ISBN: 978-1-4673-6831-5.

Dondolo, H. B. (2017). 'Negative factors of beliefs toward advertising on Facebook and their effect on attitude', Problems and Perspectives in Management, Vol. 15, No. 2, pp. 404-410.

Ducoffe, R. H. (1995). 'How consumers assess the value of advertising', Journal of Current Issues \& Research in Advertising, Vol. 17, pp. 1-18.

Ducoffe, R. H. (1996) “Advertising Value and Advertising on the Web”, Journal of Advertising Research, Vol. 36, No. 5, pp. 21-35.

Duffet, R. G. (2015a). 'The influence of Facebook advertising on cognitive attitudes amid Generation Y', Electronic Commercial Research, Vol. 15, pp. 243-267.

Duffet, R. G. (2015b). 'Facebook advertising's influence on intention-to-purchase and purchase amongst Millennials', Internet Research, Vol. 25, No. 4, pp. 498-526.

Eleboda, S. S., Majekodunmi, B., E. (2015). 'Upsurge of Social Media Advertising (SMA) in the

Nigerian Financial Services Sector: Are the Youths Ready', American Journal of Marketing research, Vol., 1, No., 2, pp. 37-44.

Ertugan, A. (2017). 'Using statistical reasoning techniques to describe the relationship between Facebook advertising effectiveness and benefits gained', Procedia Computer Science, No. 120, pp. 132-139. 
Ferreira, F. and Barbosa, B. (2017). 'Consumers' attitude toward Facebook advertising'. Int. J. Electronic Marketing and Retailing, Vol. 8, No. 1, pp. 45-57.

Gaber, H. R. and Wright L. T. (2014). 'Fast-food advertising in social media. A case study on Facebook in Egypt', Journal of Business and Retail Management Research, Vol. 9, No. 1, pp. 52-63.

Gironda, J. T., and Korgaonkar, P. K. (2014). 'Understanding consumers' social networking site usage', Journal of Marketing Management, Vol. 30, No. 5/6, pp. 571-605.

Ha, L. (2008). 'Online Advertising Research in Advertising Journals: A Review', Journal of Current Issues \& Research in Advertising, Vol. 30, No. 1, pp. 31-48.

Hadija, Z., Barnes, S. and Hair, N. (2012). 'Why we ignore social networking advertising'. Qualitative Market Research: An International Journal, Vol. 15, No.1, pp. 19-32.

Haida, A. and Rahim, H. (2015). 'Social Media Advertising Value: A Study on Consumer's Perception', International Academic Research Journal of Business and Technology, Vol. 1, No. 1, pp. 1-8.

Hair, F., Barry B., Arthur H. and Phillip, S. (2003). 'Essentials of Business Research Methods'. New York: John Wiley \& Sons.

Hajarian, H., Bastanfard, A., Mohammadzadeh, J., and Khalilian, M. (2017). 'Introducing fuzzy like in social networks and its effects on advertising profits and human behavior', Computers in Human Behavior, No. 77, pp. 282-293.

Hanaysha, J. (2016), 'The Importance of Social Media Ads in Enhancing Brand Equity: A Study on Fast Food Restaurant Industry in Malaysia', International Journal of Innovation, Management and Technology, Vol. 7, No. 2, pp. 46-51.

Hayes, J. L., King, K. W. and Ranirez Jr., A. (2016). 'Brands, Friends, \& Viral Advertising: A Social Exchange Perspective on the Ad Referral Processes', Journal of Interactive Marketing, Vol. 36, pp. 31-45.

Huang, J., Su, S., Zhou, L. and Liu, X. (2013). 'Attitude toward the Viral Ad: Expanding Traditional Advertising Models to Interactive Advertising', Journal of Interactive Marketing, Vol. 27, pp. 36-46.

John, L. K., Emrich, O., Gupta, S., and Norton, M. I. (2017), "Does 'Liking' Lead to Loving? The Impact of Joining a Brand's Social Network on Marketing Outcomes," Journal of Marketing Research, 54 (1), 144-155. doi: http://dx.doi.org/10.1509/jmr.14.0237

Jung, S., Lin, S., Carlson, J. R. and Ross Jr., W. T. (2016). 'Brand engagement on social media: will firms' social media efforts influence search engine advertising effectiveness?'. Journal of Marketing Management, Vol. 30, No. 5/6, pp. 526-557.

Kamal, S. and Chu, S. (2012). 'Beliefs, attitudes, and behaviors toward advertising on social media in the Middle East: a study of young consumers in Dubai, United Arab Emirates'. Int. J. Internet Marketing and Advertising, Vol. 7, No. 3, pp. 237- 259 .

Kelly, L, Kerr, G., and Drennan, J. (2010). 'Avoidance of advertising on social networking sites: The teenage perceptive', Journal of Interactive Advertising, Vol. 10, No. 2, pp. 16-27.

Ketelaar, P. E., Janssen, L., Vergeer, M., van Reijmersdal, E. A., Crutzen, R. and van’t Riet, J. (2016). 'The success of viral ads: Social and attitudinal predictors of consumer pass-on behavior on social network sites', Journal of Business Research, Vol. 69, pp. 2603-2613.

Khang, H., Ki, E. and Ye, L. (2012). 'Social Media Research in Advertising, Communication, Marketing, and Public Relations, 1997-2010', Journalism \& Mass Communication Quarterly, Vol. 89, No. 2, pp. 279-298.

Kim, S., Jeong, S. and Hwang, T. (2016). 'Why are there cross-national differences in response to comparative advertising?: some mediators', Journal of Marketing Communications (2016), pp. 1-19.

Kim, D. H., Seely, N. K. and Jung, J. H. (2017). 'Do you prefer, Pinterest or Instagram? The role of image-sharing SNSs and self-monitoring in enhancing ad effectiveness', Computers in Human Behavior, Vol. 70, pp. 535-543.

Kim, J. and McMillan, S. J. (2008). 'Evaluation of Internet advertising research: A bibliometric analysis of citations from key sources'. Journal of Advertising, Vol. 37, No. 1, pp. 99-112.

Kim, S., Lee, J. and Yoon, D. (2015). 'Norms in Social Media: The Application of Theory of Reasoned Action and Personal Norms in Predicting Interactions with Facebook Page Like Ads', Communication Research Reports, Vol. 32, No. 4, pp. 322-331.

Kim, Y., Kang, M., Choi, S. M. and Sung, Y. (2016). 'To click or not to click? Investigating antecedents of advertisement clicking on Facebook', Social Behavior and Personality, Vol. 44, No. 4, pp. 657-558.

Knoll, J. (2016), 'Advertising in social media: a review of the empirical evidence', International Journal of Advertising, Vol. 35, No. 2, pp. 266-300.

Knoll, J. and Schramm, H. (2015). 'Advertising on social network sites - Investigating the social influence of user-generated content on online advertising effects'. Communication, Vol. 40, No. 3, pp. 341-360.

Kotler, Ph., Armstrong, G., Harris. L. and Piercy, N. (2016). 'Principles of Marketing $7^{\text {th }}$ European Edition' Pearson Education Limited, Harlow, United Kingdom.

Lawlor, M. A., Dunne, Á. and Rowley, J. (2016). 'Young consumers' brand communications literacy in a social networking site context', European Journal of Marketing, Vol. 50, No. 11, pp. 2018-2040.

Lee, J. and Hong, I. B. (2016). 'Predicting positive user responses to social media advertising: The roles of emotional appeal, informativeness, and creativity', International Journal of Information Management, Vol. 36, pp. 360-373.

Lee, J., Kim, M., Ham, Ch. and Kim, S. (2017). 'Do you want me to watch this ad on social media?: The effects of norms on online video ad watching', Journal of Marketing Communications, Vol. 23, No. 5, pp. 456-472.

Li, Y., Lee, Y. and Lien, N. (2012). 'Online Social Advertising via Influential Endorsers', International Journal of Electronic Commerce, Vol. 16, No. 3, pp. 119-153. 
Li, Y., Lin, L. and Chiu, S. (2014). 'Enhancing Targeted Advertising with Social Context Endorsement', International Journal of Electronic Commerce, Vol. 19, No. 1, pp. 99-128.

Liu, C. (2014). 'The impact of social cues and effectiveness in check-in advertising', Kybernetes, Vol. 43, No. 7, pp. 984-1002.

Logan, K., Bright, L. F. and Gangadharbatla, H. (2012). 'Facebook versus television: advertising value perceptions among females'. Journal of Research in Interactive Marketing, Vol. 6, No. (3), pp. 164-179.

Luna-Nevarez, C. and Torres, I. M. (2015). 'Consumer Attitudes toward Social Network Advertising', Journal of Current Issues \& Research in Advertising, Vol. 36, pp. 1-19.

Mahalangu, H. B. (2014). 'The Effect of Product Information and Information Privacy Concerns on Acceptance of Facebook Advertising', Mediterranean Journal of Social Sciences, Vol. 5, No. 25, pp. 198-204.

Martínez-Navarro, J. and Bigné, E. (2017). 'The Value of Marketer-Generated Content on Social Network Sites: Media antecedents and behavioral response'. Journal of Electronic Commerce Research, Vol. 18, No. 1, pp. 52-72.

Miller, R. and Lammas, N. (2012). 'Social media and its implications for viral marketing', Asia Pacific Public Relations Journal, Vol. 11, pp. 1-9.

Mir, I. (2012). 'Consumer Attitudinal Insights about Social Media Advertising: A South Asian Perspective'. The Romanian Economic Journal, Vol. 15, No. 45, pp. 265-288.

Mir, I. (2014). 'Effects of Pre-Purchase Search Motivation on User Attitudes toward Online Social Network Advertising: A Case of University Students', Journal of Competitiveness, Vol. 6, No. 2, pp. 42-55.

Mir, I. (2015). 'Effects of Beliefs and Concerns on User Attitudes toward Online Social Network Advertising and Their Ad Clicking Behavior'. Journal of Internet Banking and Commerce, Vol. 20, No. 2, pp. 1-25.

Mir, I. (2017). 'Impact of Entertainment Motivational Drivers on User Acceptance of Online Social Network Banner Advertising: A Gratification Perspective', Zagreb International Review of Economics \& Business, Vol. 20, No. 1, pp. 19-47.

Morris, J. D., Choi, Y. and Ju, I. (2016). 'Are Social Marketing and Advertising Communications (SMACs) Meaningful?: A Survey of Facebook User Emotional Responses, Source Credibility, Personal Relevance, and Perceived Intrusiveness', Journal of Current Issues \& Research in Advertising, Vol. 37, No. 2, pp. 165-182.

Muk, A., and Chung, C. (2014). 'Driving Consumers to Become Fans of Brand Pages: A Theoretical Framework'. Journal of Interactive Advertising, Vol. 14, No. 1, pp. 1-10.

Mukherjee, K. and Banerjee, N. (2017). 'Effect of Social Networking Advertisements on Shaping Consumers' Attitude', Global Business Review, Vol. 18, No. 5, pp. 1291-1306.

Natarajan, T., Balakrishnan, J., Balasubramanian S. and Manickavasagam, J. (2014), 'Perception of Indian consumers towards social media ads in Facebook, LinkedIn, YouTube and Twitter', Int. J. Internet Marketing and Advertising, Vol. 8, No. 4, pp. 264-284.

Natarajan, T., Balakrishnan, J., Balasubramanian S.A. and Manickavasagam J. (2015). 'Examining beliefs, values, and attitudes towards social media ads: results from India', Int. J. Business Information Systems, Vol. 20, No. 4, pp. 427-454.

Okazaki, S., Rubio, N. and Campo, S. (2014). 'Gossip in social networking sites; why people chitchat about ad campaigns', International Journal of Market Research, Vol. 56, Issue 3, pp. 49-72.

Okazaki, S. and Taylor, C. R. (2013). 'Social media and international advertising: theoretical challenges and future directions', International Marketing Review, Vol. 30, No. 1, pp. 56-71.

Olney, J. T., Hollbrook, M. B. and Batra, R. (1991). 'Consumer Responses to Advertising: The Effects of Ad Content, Emotions, and Attitude toward the Ad on Viewing Time', Journal of Consumer Research, Vol. 17, No. 4, pp. 440-453.

Preston, Ivan L. (1982). 'The Association Model of the Advertising Communication Process', Journal of Advertising, Vol. 11, No. 2, pp. 3-15.

Pinho, J. C., and Soares, A. M. (2015). 'Response to advertising on social networking sites: the role of social capital', International Journal of Consumer Studies, Vol. 39, pp. 239-248.

Podsakoff, P. M., MacKenzie, S. B., Bacharach, D. G. and Podsakoff, N. P. (2005). 'The influence of management journals in the 1980s and 1990s'. Strategic Management Journal, Vol. 26, pp. 473-88.

Pollay, R. W., and Mittal, B. (1993). 'Here's the Beef: Factors, Determinants, and Segments in Consumer Criticism of Advertising”, Journal of Marketing, Vol. 57, pp. 99-114.

Prendergast, G., Liu, P. Y. and Poon, D. T. Y. (2009). ‘A Hong Kong study of advertising credibility', Journal of Consumer Marketing, Vol. 26, No. 5, pp. 320-329.

Rambe, P. and Jafeta, R. J. (2017). 'Impact Of Social Media Advertising On High Energy Drink Preferences And Consumption', The Journal of Applied Business Research, Vol. 33, No. 4, pp. 653-668.

Ramirez, A. and Cox, Ch. (2012). 'Improving on the Range Rule of Thumb', Rose-Hulman Undergraduate Mathematics Journal, Vol. 13, No. 2, pp. 1-13.

Royo-Vela, M. and Casamassima, P. (2011). 'The influence of belonging to virtual brand communities on consumers' affective commitment, satisfaction, and word-of-mouth advertising', Online Information Review, Vol. 35, No. 11, pp. 517-542.

Sabri, O. and Michel, G. (2014). 'When Do Advertising Parodies Hurt? The Power of Humor and Credibility in Viral Spoof Advertisements', Journal of Advertising Research, June 2014, pp. 43-57.

Saxena, A. and Khanna, U. (2013). 'Advertising on Social Network Sites: A Structural Equation Modelling Approach' Vision: The Journal of Business Perspective, Vol. 17, No. 1, pp. 17-25. 
Schrammel, J., Koffel, C. and Tscheligi, M. (2009). 'How much do you tell? Information disclosure behavior in different types of online communities'. Proceedings of the 14th International Conference on Communities and Technology. Pennsylvania, USA, pp. 275-284.

Shareef, M. A., Mukerji, B., Dwivedi, Y. K., Rana, N. P., and Isalm, R. (2017). 'Social media marketing: Comparative effect of advertisement sources', Journal of Retailing and Consumer Services, http://dx.doi.org/10.1016/j.jretconser.2017.11.001

Sheehan, K. B. (2002), "Online Research Methodology: Reflections and Speculations," Journal of Interactive Advertising, Vol. 3, No. 1.

Shen, G., Chiou, J., Hsiao, Ch., Wang, Ch. and Li, H. (2016). 'Effective marketing communication via social networking site: The moderating role of the social tie', Journal of Business Research, Vol. 69, pp. 2265-2270.

Singh, R. (2016). 'Monotony of social networking among millennial and its effect on social advertisement: a challenge to digital marketers', YOUNG CONSUMERS, Vol. 17, No. 4, pp. 376-387.

Smit, E., van Reijmersdal, E. and Neijens, P. (2009). "Today's practice of brand placement and the industry behind it", International Journal of Advertising, Vol. 28, No. 5, pp. 761-782.

Smith, A.N., Fischer, E. and Yongjian C. (2012). 'How Does Brand-related User-generated Content Differ across YouTube, Facebook, and Twitter?' Journal of Interactive Marketing, Vol. 26, pp. 102-113.

Spears, R., Lea, M. Postmes, T. and Wolbert. A. (2011). 'A side look at computer-mediated interaction'. In: Strategic uses of social technology. An interactive perspective of social psychology, ed. Birchmeier, Z., Dietz-Uhler, B and Stasser, G., Cambridge, UK and New York: Cambridge University Press., pp. 16-39.

Statista (2015) "Facebook Global User Age Distribution" [online] Available at: <http://www.statista.com/statistics/376128/facebook-global-user-age-distribution/> [accessed date: $24^{\text {th }}$ June, 2015]

Tan, W. J., Kwek, C. L. and Li, Z. (2013). 'The Antecedents of Effectiveness Interactive Advertising in the Social Media', International Business Research, Vol. 6, No. 3, pp. 88-99.

Taylor, D. G., Lewin, J. E. and Strutton, D. (2011). 'Friends, Fans, and Followers: Do Ads Work on Social Networks? How Gender and Age Shape Receptivity', Journal of advertising research (March 2011), pp. 258-275.

Thornhill, M. Xie, K. and Lee Y. J. (2017). 'Social media advertising in a competitive market: Effects of earned and owned exposures on brand purchase", Journal of Hospitality and Tourism Technology, Vol. 8, No. 1, pp. 87-100.

Tinko (2017). 'Measuring performance of Facebook advertising based on media used: a case study on online shops in Indonesia', Procedia Computer Science, Vol. 111, pp. 105-112.

Tran, T. P. (2017). 'Personalized ads on Facebook: An effective marketing tool for online marketers', Journal of Retailing and Consumer Services, Vol. 39, pp. 230-242.

van Noort, G., Antheunis, M. L. and Verlegh, P. W. J. (2014). 'Enhancing the effects of social network site marketing campaigns If you want consumers to like you, ask them about themselves', International Journal of Advertising, Vol. 33, No. 2, pp. 235-252.

Vanwesenbeeck, I., Ponnet, K. and Walrave, M. (2017). 'Young adolescents' advertising literacy and purchase intention in social network games: Influence of perspective taking and need for cognition', Journal of Consumer Behaviour, Vol. 16, pp. 23-33.

Vassileva, B. (2017). 'Consumer Activities and Reactions to Social Network Marketing', Management, Vol. 12, No. 2, pp. 133-144.

Voorveld, H. A., and van Noort, G. (2014). 'Social Media in Advertising Campaigns Examining the Effects on Perceived Persuasive Intent, Campaign and Brand Responses', Journal of Creative Communications, Vol. 9, No. 3, pp. $253-268$.

Wang, R. and Huang, Y. (2017). 'Going Native on Social Media: The Effects of Social Media Characteristics on Native Ad Effectiveness', Journal of Interactive Advertising, Vol. 17, No. 1, pp. 41-50.

Walrave, M., Poels, K., Antheunis, M. L., Van den Broeck, E. V., and van Noort, G. (2016). 'Like or dislike? Adolescents' responses to personalized social network site advertising', Journal of marketing communications, pp. 1-18.

Yaakop, A., Marhana, M.A. and Khatijah, O. (2013). 'like it or Not: Issue of Credibility in Facebook Advertising'. Asian Social Science, Vol. 9, No. 3, pp. 154-163.

Yousif, R. O. (2009). 'The Extent of Facebook Users' Interest in the Advertising Messages', International Journal of Marketing Studies, Vol. 4, No. 3, pp. 122-133.

Zarouali, B., Ponnet, K., Walrave, M. and Poels, K. (2017). “"Do you like cookies?” Adolescents' skeptical processing of retargeted Facebook-ads and the moderating role of privacy concern and a textual debriefing', Computers in Human Behavior, Vol. 69, pp. 157-165.

Zeng, F., Huang, L. and Dou, W. (2009). 'Social Factors in User Perceptions And Responses To Advertising In Online Social Networking Communities', Journal of Interactive Advertising, Vol. 10, No. 1, pp. 1-13.

Zhang, J. and Mao, E. (2016). 'From Online Motivations to Ad Clicks and to Behavioral Intentions: An Empirical Study of Consumer Response to Social Media Advertising', Psychology \& Marketing, Vol. 33, No. 3, pp. 155-164.

Zhang, L. and Peng, T. (2015). 'Breadth, depth, and speed: diffusion of advertising messages on microblogging sites', Internet Research, Vol. 25, No. 3, pp. 453-470. 